\title{
Editorial for the series on pain therapy
}

Pain symptoms are relatively frequent both in children and adults. The progress which has been achieved in the field of the pain therapy is a remarkable success history. This progress has been obtained as the result of basic research and the testing of new knowledge through clinical trials.

In this series, recent developments on the assessment and pain management have been presented. The authors focused their attention on a wide field of applications: from new delivery systems for analgesics to pain assessment in clinical trials or interventional management of neuropathic pain.

Despite novel data on the pain treatment, there are specific clinical scenarios that remain a challenging area with many concerns about the best therapy and unmet therapeutic needs. This Special Issue aims to contribute to further understanding into the pain mechanisms and provides specific tools for the development of new therapies in order to improving the quality of life of patients suffering from pain.

We are thankful of all authors for their contributions to the present series. We hope you enjoy these interesting manuscripts.

\section{Acknowledgments}

Funding: None.

\section{Footnote}

Provenance and Peer Review: This article was commissioned by the editorial office, Annals of Translational Medicine for the series "Pain Therapy". The article did not undergo external peer review.

Conflicts of Interest: The author has completed the ICMJE uniform disclosure form (available at http://dx.doi.org/10.21037/ atm-2020-pt-06). The series "Pain Therapy" was commissioned by the editorial office without any funding or sponsorship. AR served as the unpaid Guest Editor of the series and serves as an unpaid editorial board member of Annals of Translational Medicine from Nov 2019 to Oct 2021. The author has no other conflicts of interest to declare.

Ethical Statement: The author is accountable for all aspects of the work in ensuring that questions related to the accuracy or integrity of any part of the work are appropriately investigated and resolved.

Open Access Statement: This is an Open Access article distributed in accordance with the Creative Commons AttributionNonCommercial-NoDerivs 4.0 International License (CC BY-NC-ND 4.0), which permits the non-commercial replication and distribution of the article with the strict proviso that no changes or edits are made and the original work is properly cited (including links to both the formal publication through the relevant DOI and the license). See: https://creativecommons.org/ licenses/by-nc-nd/4.0/. 


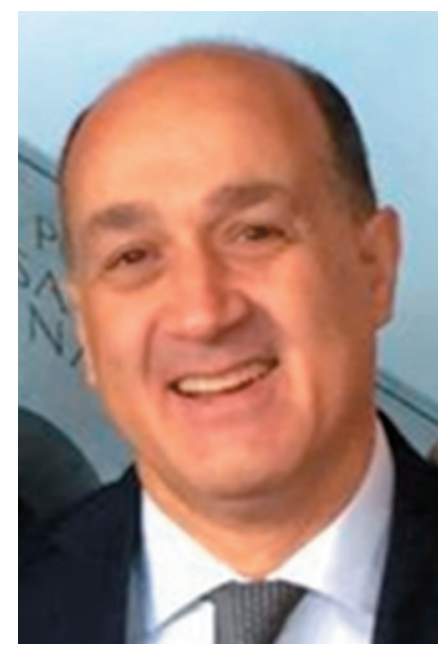

Antonio Ruggiero

Antonio Ruggiero

Pediatric Oncology Unit, Fondazione Policlinico Universitario A. Gemelli IRCCS, Universita' Cattolica del Sacro Cuore, Rome, Italy. (Email: antonio.ruggiero@unicatt.it)

Submitted Oct 24, 2020. Accepted for publication Dec 15, 2020. doi: $10.21037 /$ atm-2020-pt-06

View this article at http://dx.doi.org/10.21037/atm-2020-pt-06

Cite this article as: Ruggiero A. Editorial for the series on pain therapy. Ann Transl Med 2021;9(2):184. doi: 10.21037/atm2020-pt-06 